\title{
Experimental study on the effect of adding bioethanol in spark ignition engine
}

\author{
Dragos Tutunea, Ilie Dumitru \\ University of Craiova, Faculty of Mechanics \\ ${ }^{*}$ Corresponding author e-mail: dragostutunea@yahoo.com \\ Article history \\ Received 10.06.2017 \\ Accepted 28.08.2017 \\ DOI https://doi.org/10.26825/bup.ar.2017.011
}

\begin{abstract}
The stricter legislation on exhaust emissions and growing demands for the use of alternative fuel requires the investigation of various blends in terms of combustion, emissions and efficiency in gasoline engines. Bioethanol-gasoline blends represent a particularly promising direction in reduction of traffic pollution which represents a major part of green-house gases. Bioethanol has a higher octane number and oxygen implying several advantages compared with gasoline in internal combustion engines. The aim of this paper is to study and analyze emissions of different blends of bioethanol-gasoline in a six cylinder gasoline engine in laboratory condition. The use of bioethanol blends decreases the $\mathrm{CO}$ and $\mathrm{HC}$ emissions and increase brake power and torque.
\end{abstract}

\section{Introduction}

The increasing demands of energy from petroleum fuels due to the growth in population and changes in lifestyle collaborated with the rapid development of industry have inspired researchers to explore other sources of energy. In the last century the trend was to exploit fossil crude oil, coal, and natural gas to meet the need of the industry. In the 21 st century the strict emissions regulations together with the depletion of petroleum reserves forced most countries to reduce greenhouse gas emissions [1,2]. The alternative fuel which can be used as substitute must be produced from renewable sources and used in internal combustion engines without modifications [3]. Alcohols like methanol and ethanol provide a solution to this problem. Bioethanol and ethanol $\left(\mathrm{C}_{2} \mathrm{H}_{5} \mathrm{OH}\right)$ is the same product with the same structural and molecular formula only differ the method of production. The bioethanol is produced from various feedstocks' such grain, sugar cane, sorghum, cassava, sunflower, cotton, molasses, cotton, many types of cellulose and other biomass [4]. The 
potential of bioethanol is represented by the low cost if is produced from industrial and municipal solid waste and agricultural residues [5]. Bioethanol has different properties compared to gasoline fuel; heating value is lower than gasoline so to achieve the same power requires more fuel; the high oxygen content promotes the combustion and high temperature of combustion; heat of vaporization is higher increasing the volumetric efficiency of the engine; octane number is higher; lower density and a high laminar flame propagation speed [4]. Al-Hasan [6] studied ethanol-gasoline fuel blends and found an increase in volumetric efficiency with $9 \%$, brake thermal efficiency with $7 \%$ and a decrease of brake specific fuel consumption BSFC with 2.4\%. Qi and Lee [7] on a three cylinder engine fueled with ethanol-gasoline blends found a peak cylinder pressure for E20 identical with gasoline. At higher engine loads the peak heat release rate (HRR) is higher and E20 have a faster combustion velocity. Rahman and Osman [8] studied various ethanol-gasoline blends at different compression rates and found the best compression rates at 8 for E10, 10 for E20 and 12 for E30. Celik [9] investigated ethanol-gasoline blends at high compression ratio and found a decrease in power with the increase of ethanol content in the blend. At E100 found a decrease in power of $4 \%$ compared with E0. Bayraktar [10] investigated the effect of ethanol addition to gasoline on engine performance and found that ethanol improve combustion and engine performance. The blend E7.5 performed better in the engine and the effective efficiency increased. Schifter et al. [11] investigated in a single cylinder gasoline engine ethanol addition in the combustion behavior and found that the blends up to $10 \%$ have minimal effects in combustion rates while in blends up to $20 \%$ combustion process slows down. Turner et al. [12] found in their researches that ethanol addition modifies the evaporation properties which increase the vapor pressure for lower blends. Also the higher content of oxygen contributes to enhance combustion and engine efficiency and faster flame speed. Bardaie and Janius [13] studied in a gasoline engine with a modified carburetor the addition of ethanol and found a loss of power by 3-4\% compared with gasoline. Yucesu et al. [14] investigated the performance of ethanol blends at 8:1 and 13:1 compression ratios and found at E60 the highest improvement in BSFC $14.5 \%$ at $3500 \mathrm{rpm}$ and $17 \%$ at $5000 \mathrm{rpm}$. In this paper the use of bioethanol was proposed to determine performance and emissions on a six cylinder SI engine.

\section{Experimental apparatus and test procedure}

\subsection{Engine descriptions and experimental setup}

The experimental setup used in this study is shown in Figure 1. A M52B20 gasoline engine to measure the performance and emissions was used to test various blends of bioethanol and gasoline. The specifications of the test engine are shown in Table 1. The test engine is mounted on a chassis which is connected to electronic display and fuel reservoir. Components of testing stand are fuel feeding installation, controller and measuring equipment. Mechanical connection between engine and motor is supported by a shaft fitted with protective shields. The electric brake is a $250 \mathrm{~kW}$ three phase electric motor controlled by the inverter and ordered by the process computer. Controller is equipped with a touch screen which is used to control the engine. Table 2 shows some important differences between gasoline and bioethanol. The bioethanol was purchased from a regional vendor. The bioethanol and gasoline were mixed by volume basis in B5 (5\% bioethanol, $95 \%$ gasoline), B10 (10\% bioethanol, $90 \%$ gasoline), B15 (15\% bioethanol, $85 \%$ gasoline) and B20 (20\% bioethanol, $80 \%$ gasoline).

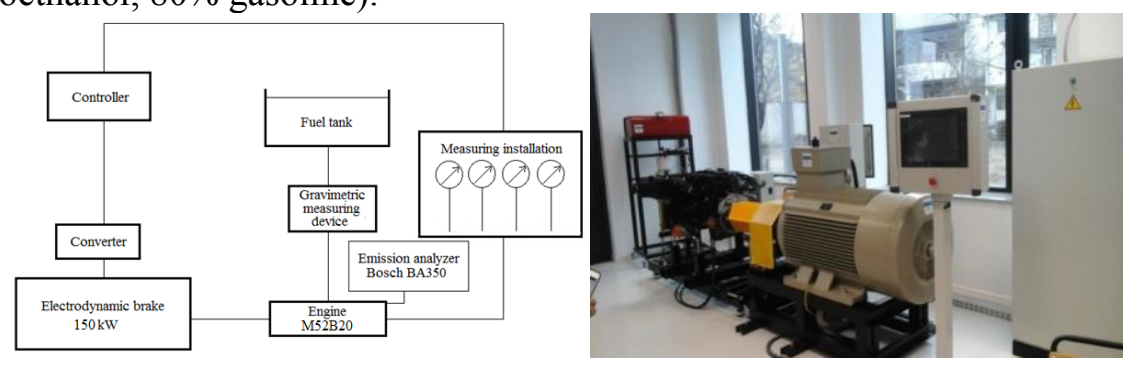

Figure 1. Schematic diagram of experimental setup 
Table 2. Specifications of M52B20 gasoline engine

\begin{tabular}{|l|l|}
\hline Configuration & Straight- 6 \\
\hline Piston stroke, $(\mathrm{mm})$ & 66 \\
\hline Cylinder bore, $(\mathrm{mm})$ & 80 \\
\hline Compression ratio & 11 \\
\hline Displacement $(1)$ & $1991 \mathrm{cc}$ \\
\hline Power output & $110 \mathrm{~kW}(150 \mathrm{HP})$ at $5,900 \mathrm{rpm}$ \\
\hline Torque output & $190 \mathrm{Nm}(140 \mathrm{lb} \cdot \mathrm{ft})$ at $4,200 \mathrm{rpm}$ \\
\hline
\end{tabular}

Table 3. Properties of fuels [4]

\begin{tabular}{|l|c|c|c|}
\hline Property & Unit & Gasoline & Bioethanol \\
\hline Chemical formula & - & $\mathrm{C}_{5}-\mathrm{C}_{12}$ & $\mathrm{C}_{2} \mathrm{H}_{5} \mathrm{OH}$ \\
\hline Molecular weight & $\mathrm{kg} \mathrm{kmol}^{-1}$ & 114.5 & 46.07 \\
\hline C-fraction & mass $\%$ & 87.4 & 52.2 \\
\hline O-fraction & mass $\%$ & 0 & 34.7 \\
\hline H-fraction & mass \% & 12.6 & 13 \\
\hline Specific gravity & - & $0.7-0.78$ & 0.794 \\
\hline Density (at $\left.15^{\circ} \mathrm{C}\right)$ & $\mathrm{kg} \mathrm{m}^{-3}$ & $750-765$ & $785-809.9$ \\
\hline Research octane no. & - & $91-100$ & $108.61-110$ \\
\hline Motor octane no. & - & $82-92$ & 92 \\
\hline Higher heating Value & $\mathrm{MJ} \mathrm{kg}^{-1}$ & 47.3 & 29.7 \\
\hline Lower heating Value & $\mathrm{MJ} \mathrm{kg}^{-1}$ & 44 & 26.9 \\
\hline Flash point & ${ }^{\circ} \mathrm{C}$ & -45 to -13 & $12-20$ \\
\hline Auto ignition temperature & ${ }^{\circ} \mathrm{C}$ & 257 & 425 \\
\hline Vapor Flammability Limits & ${ }^{\circ} \%{ }^{\circ} \%$ & $0.6-8$ & $3.5-15$ \\
\hline
\end{tabular}

\subsubsection{Measurement instrumentation}

The main instruments used in the tests are as follows:

a. The engine load and speed was controlled using controller equipped with a touch screen.

b. A BEA350 gas analyzer was used to measure $\mathrm{CO}$ (vol\%), $\mathrm{CO}_{2}$ (vol\%), $\mathrm{HC}(\mathrm{ppm}), \mathrm{O}_{2}$ (vol\%), $\lambda$ and NOx (ppm).

c. The temperature of engine coolant, oil and exhaust gas has been measured with temperature sensors.

\section{Results and discussion}

Figure 2 shows the effect of different blends of bioethanol on the engine brake power for different engine speeds. It is observed slight increases $(1-4 \%)$ of brake power when the bioetahanol content in the fuel is increased.

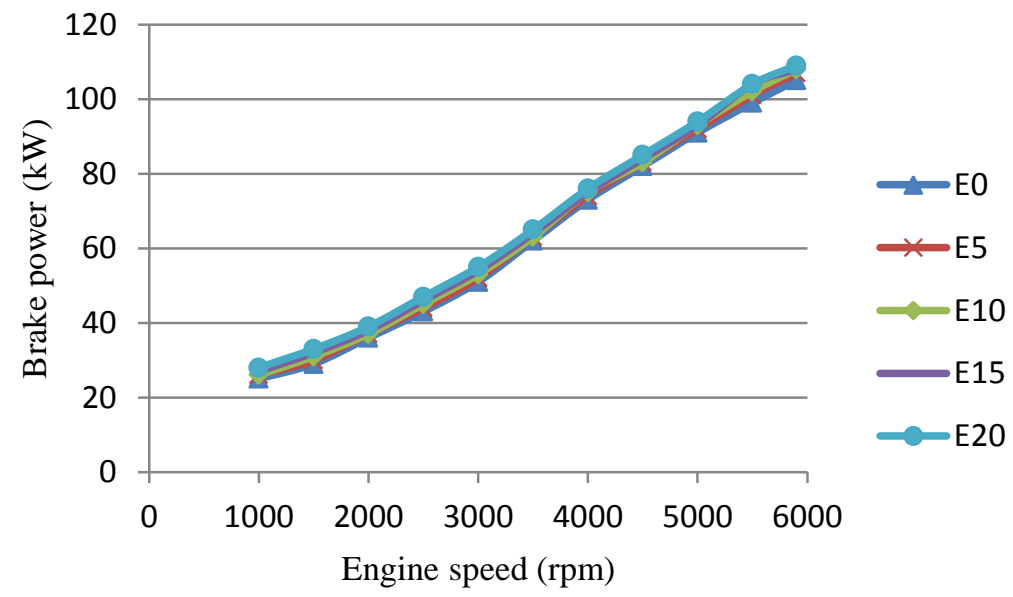

Figure 2. Experimental results of brake power at different fuel blends and engine speeds 
This rise of power may be to the indicated mean effective pressure for higher bioetahnol blends [10]. Higher bioethanol percentage increases the density of the blend and volumetric efficiency causing the increase of power [6]. Celik [9] observed an increase for E25, E50 and E75 with 3, 6 and $2 \%$ in a single cylinder water cooled engine. Ozsezen and Canakci [15] found an increase for E5 and E10 of 2,2 - 1,1\% in wheel power in a four cylinder MPFI SI engine. Najafi et al. [16] found an increase also in the brake power for E5, E10, E15 and E20 in a four cylinder SOHC engine. As summary the literature reported an increase in brake power for lower blends with a decline in the higher percentage of bioethanol. Figure 3 shows the effect of different blends of bioethanol on engine torque for different engine speeds. The increase of bioethanol in the blend increases the torque of the engine between $1-2 \%$. The higher content of bioethanol produces lean mixtures increasing the relative air-fuel ratio making combustion more efficient [17]. Also the addition of bioethanol increases the octane number resulting in higher combustion pressure and torque. Deh Kiani et al. [18] observed an increase in torque in lower blends E5-E20 in a four cylinder water cooled engine. Topgul et al. [19] found 4.26\% increase in torque for E60 in 1 cylinder water cooled engine. Balki et al. [20] observed a 3.6\% rise of torque for E100 in 1 cylinder $2 \mathrm{~kW}$ engine.

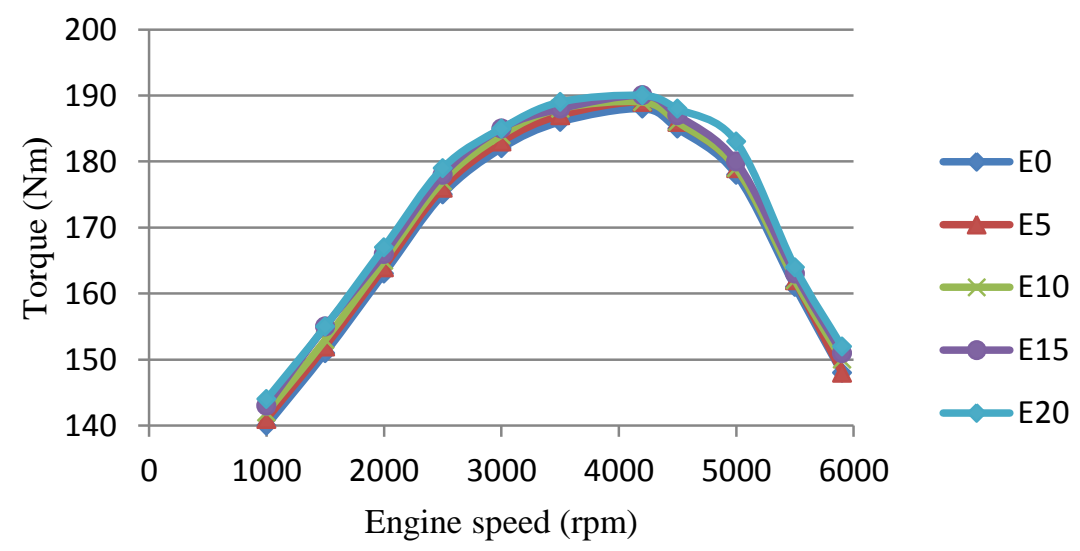

Figure 3. Experimental results of torque at different fuel blends and engine speeds

Figure 4 shows the effect of different blends of bioethanol on $\mathrm{CO}$ emission for different engine speeds. The addition of bioethanol decreases the $\mathrm{CO}$ emissions which mean that the process of combustion is tuned to be completed. The CO concentration at $3500 \mathrm{rpm}$ for E0, E5, E10, E15 and E20 was 3.55, 3.45, 3.38, 3.27 and $3.16(\% \mathrm{~V})$. The reduction comparative with gasoline was for E5 of $2.89 \%$, E10 of $5.03 \%$, E15 of $8.56 \%$ and E20 of $12.34 \%$. The reduction in CO emissions is due to the fact that bioethanol has less carbon content than gasoline and more oxygen which increases the oxygen-to-fuel ratio [9]. Balki and Sayin [21] observed a for pure ethanol a reduction of $35 \%$ in $\mathrm{CO}$ emissions compared to gasoline. Ghazikhani et al. [22] observed for E15 a reduction of $71 \%$ in $\mathrm{CO}$ in $1 \mathrm{C}$ engine. Also Chen et al. [23] observed for E5 - E30 a 50\% reduction in a four cylinder SI engine. Figure 5 shows the concentrations of $\mathrm{CO}_{2}$ emission for different engine speeds. The addition of bioethanol increases the $\mathrm{CO}_{2}$ emissions as a result of improved combustion. The $\mathrm{CO} 2$ concentration at $3500 \mathrm{rpm}$ for E0, E5, E10, E15 and E20 was 12.05, 12.21, 12.32, 12.41 and 12.50 $(\% \mathrm{~V})$. The increase comparative with gasoline was for E5 of $1.32 \%$, E10 of $2.24 \%$, E15 of $2.98 \%$ and E20 of 3.73\%. Hsieh et al. [17] observed for E5 to E30 an increase of $\mathrm{CO}$ emissions between 5 $-25 \%$ in a four cylinder MPFI engine. Also Al-Hasan [6] obtained for E20 comparative with E20 an increase of $75 \%$ of $\mathrm{CO} 2$ emissions in a four cylinder engine. 


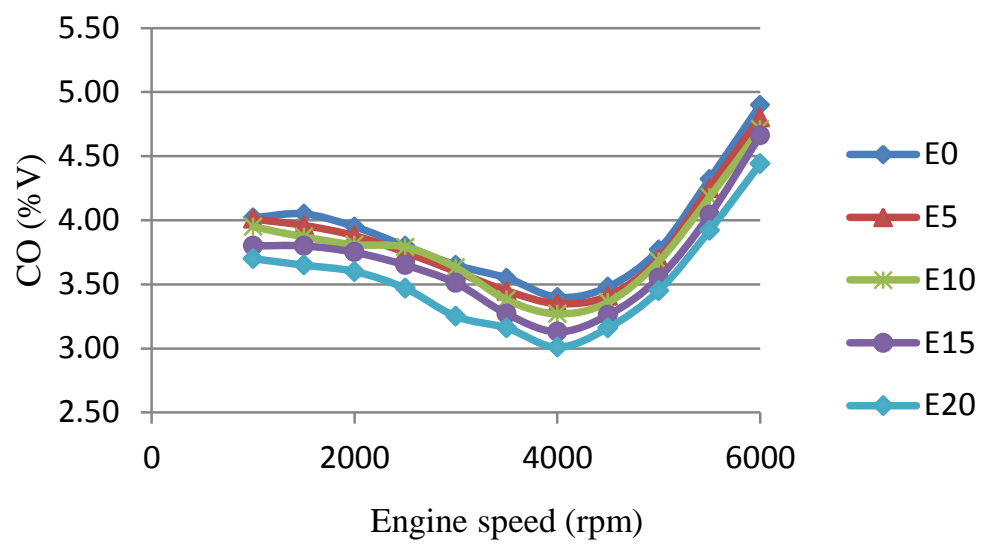

Figure 4. Experimental results of $\mathrm{CO}$ emissions at different fuel blends and engine speeds

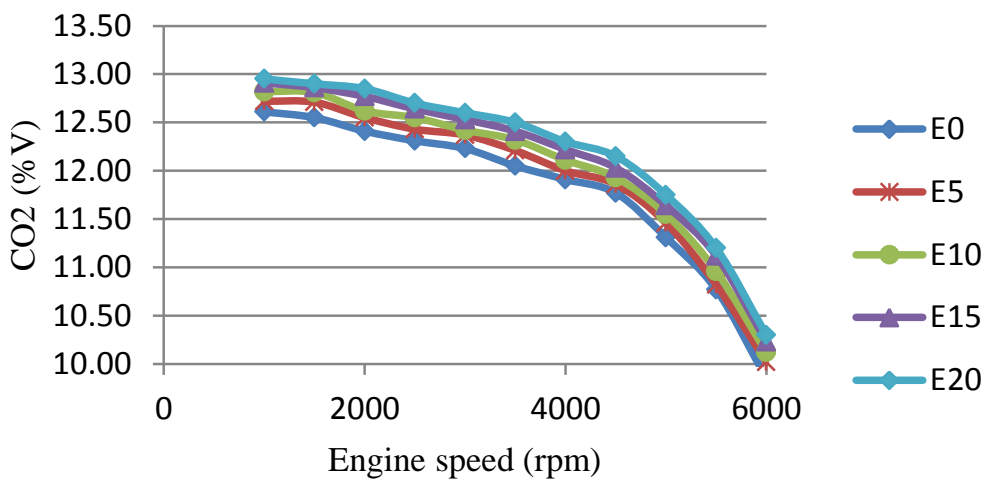

Figure 5. Experimental results of $\mathrm{CO}_{2}$ emissions at different fuel blends and engine speeds

Figure 6 shows the concentrations of $\mathrm{HC}$ emission for different engine speeds. The addition of bioethanol decreases the $\mathrm{HC}$ emissions as results of complete combustion. The $\mathrm{HC}$ concentration at $3500 \mathrm{rpm}$ for E0, E5, E10, E15 and E20 was 243, 234, 233, 217 and $212(\% \mathrm{~V})$. The increase comparative with gasoline was for E5 of 3.84\%, E10 of 8.96\%, E15 of $11.98 \%$ and E20 of $14.62 \%$. Ozsezen et al. [15] observed for E5 and E10 a reduction of 14\% in $\mathrm{HC}$ emissions in a four cylinder engine. Hsieh et al. [17] found for E5- E30 a reduction of $20-80 \%$ in $\mathrm{HC}$ emissions. He et al. [24] found for $\mathrm{E} 10$ and $\mathrm{E} 30$ a reduction of $53.4 \%$ of $\mathrm{HC}$ emissions.

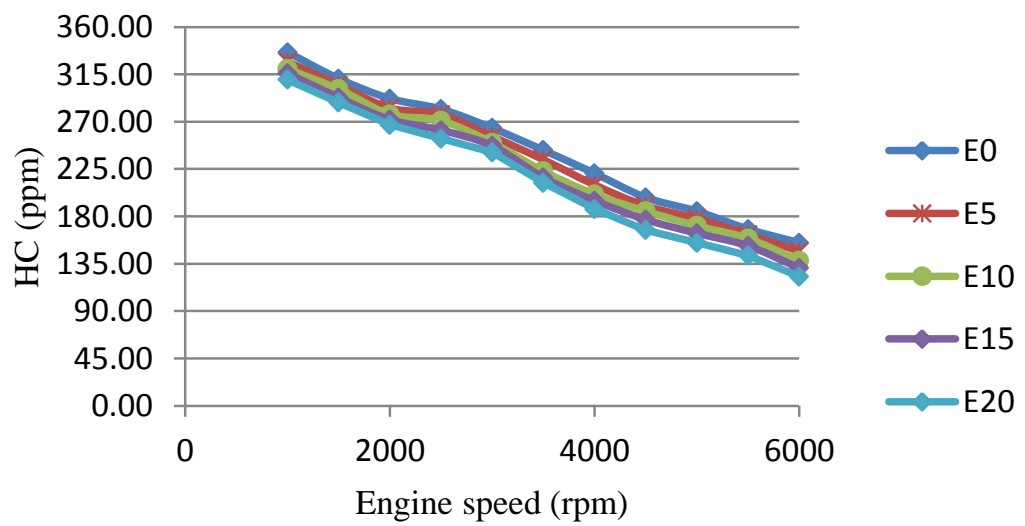

Figure 6. Experimental results of $\mathrm{HC}$ emissions at different fuel blends and engine speeds 


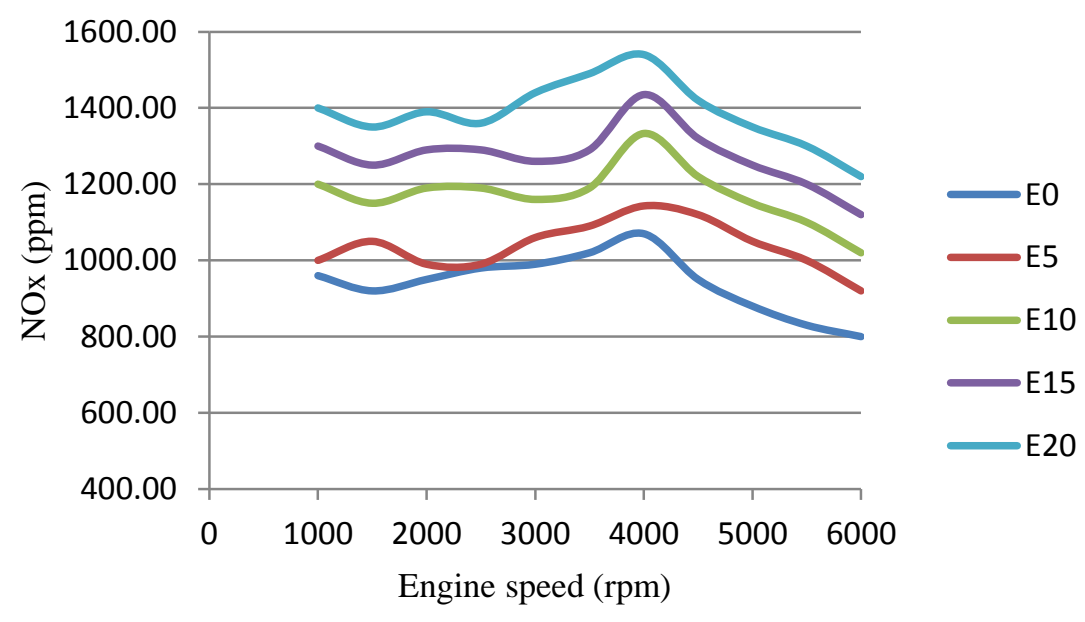

Figure 7. Experimental results of NOx emissions at different fuel blends and engine speeds

Figure 7 shows the concentrations of NOx emission for different engine speeds. As the percentage of bioethanol in the blends increased the emissions of NOx increased. The NOx concentration at $3500 \mathrm{rpm}$ for E0, E5, E10, E15 and E20 was 1020, 1092, 1191, 1296 and $1493(\% \mathrm{~V})$. The increase comparative with gasoline was for E5 of $6.86 \%$, E10 of $16.76 \%$, E15 of $27.05 \%$ and E20 of 46.37\%. Najafi et al. [16] found for E5, E10, E15 and E20 an increase in NOx emissions by $12.57 \%, 33.94 \%, 33.6 \%$ and $45.55 \%$ in comparison to gasoline. Also, Schifter et al. [11] for a single cylinder SI engine using blends of ethanol $(0-20 \%)$ fond that NOx emission increased with ethanol addition comparative to gasoline.

\section{Conclusions}

The present work evaluates the performance and environmental effects of using various blends of bioethanol-gasoline in a six cylinder SI engine. The experimental results that the bioethanol addition increase the brake power and torque for all blends tested. Bioethanol is an oxygenated fuel which produces leaner operations and a better combustion. With use of the bioethanol-gasoline blends was found a reduction in $\mathrm{CO}(2.89 \%$ with E5 and $12.34 \%$ with E20) and $\mathrm{HC}(3.84 \%$ with E5 and $14.62 \%$ with E20) and an increase in $\mathrm{CO}_{2}\left(1.32 \%\right.$ with $\mathrm{E} 5$ and $3.73 \%$ with E20) and $\mathrm{NO}_{\mathrm{X}}$ (6.86\% with E5 and $46.37 \%$ with E20).

\section{References}

[1] Chandra R., Takeuchi H., Hasegawa T., 2012, Methane production from lignocellulosic agricultural crop wastes: a review in context to second generation of biofuel production, Renewable and Sustainable Energy Reviews, 16 (3), pp.1462-76.

[2] Demirbas A., 2007, Progress and recent trends in biofuels, Prog Energy Combust Sci, 33, pp. 1-18.

[3] Koc M., Sekmen Y., Topgul T., Yucesu H.S., 2009, The effects of ethanol-unleaded gasoline blend on engine performance and exhaust emissions in a spark-ignition engine, Renewable Energy, 34, pp. 2101-6.

[4] Masum B.M., Masjuki H.H., Kalam M.A., Rizwanul Fattah I.M., Palash S.M., Abedin M.J., 2013, Effect of ethanol-gasoline blend on NOx emission in SI engine, Renewable and Sustainable Energy Reviews, 24, pp. 209-222.

[5] Limayem A., Ricke S.C., 2012, Lignocellulosic biomass for bioethanol production: current perspectives, potential issues and future prospects, Prog Energy Combust Sci, 38, pp. 449-67.

[6] Al-Hasan M., 2003, Effect of ethanol-unleaded gasoline blends on engine performance and exhaust emission, Energy Convers Manag, 44, pp. 1547-61.

[7] Qi D.H., Lee C.F., 2016, Combustion and emissions behaviour for ethanol-gasoline- blended fuels in a multipoint electronic fuel injection engine, Int J Sustain Energy, 35, pp. 323-38.

[8] Abdel-Rahman A.A., Osman M.M., 1997, Experimental investigation on varying the compression ratio of SI engine working under different ethanol-gasoline fuel blend, Int. J. Energy Res, 21, pp. 
$31-40$.

[9] Celik M.B., 2008, Experimental determination of suitable ethanol-gasoline blend rate at high compression ratio for gasoline engine, Appl Therm Eng, 28, pp. 396-404.

[10] Bayraktar H., 2005, Experimental and theoretical investigation of using gasoline-ethanol blend in spark-ignition engines, Renew Energy, 30, pp.733-47.

[11] Schifter I., Diaz L., Rodriguez R, Gomez JP, Gonzalez U., 2011, Combustion and emissions behavior for ethanol-gasoline blends in a single cylinder engine, Fuel 2011, 90, pp. 3586-92.

[12] Turner D., Xu H., Cracknell R.F., Natarajan V., Chen X., 2011, Combustion performance of bioethanol at various blend ratios in a gasoline direct injection engine, Fuel, 90, pp. 1999-2006.

[13] Bardaie M.Z, Janius R., 1984, Conversion of spark-ignition engine for alcohol usage- comparative performance, Agricultural Mechanization in Asia-Africa and Latin America, 15(2), pp.31-4.

[14] Yucesu H.S., Topgul T., Cinar C., Okur M., 2006, Effect of ethanol-gasoline blend on engine performance and exhaust emissions in different compression ratios, Applied Thermal Engineering, 26, pp. 2272-8.

[15] Ozsezen A.N., Canakci M., 2011, Performance and combustion characteristics of alcoholgasoline blends at wide-open throttle, Energy, 36, pp. 2747-52.

[16] Najafi G., Ghobadian B., Tavakoli T., Buttsworth D.R., Yusaf T.F., Faizollahnejad M., 2009, Performance and exhaust emissions of a gasoline engine with ethanol blended gasoline fuels using artificial neural network, Appl Energy, 86, pp. 630-9.

[17] Hsieh W.D., Chen R.H., Wu T.L., Lin T.H., 2002, Engine performance and pollutant emission of an SI engine using ethanol-gasoline blended fuels., Atmos Environ, 36, pp. 403-10.

[18] Deh Kiani M.K., Ghobadian B., Tavakoli T., Nikbakht A.M., Najafi G., 2010, Application of artificial neural networks for the prediction of performance and exhaust emissions in SI engine using ethanol-gasoline blends, Energy, 35, pp. 65-9.

[19] Topgul T., Yucesu H.S., Cinar C., Koca A., 2006, The effects of ethanol-unleaded gasoline blends and ignition timing on engine performance and exhaust emissions, Renew Energy, 31, pp. 2534-42.

[20] Balki M.K., Sayin C., Canakci M., 2014, The effect of different alcohol fuels on the performance, emission and combustion characteristics of a gasoline engine, Fuel, 115, pp. 901-6.

[21] Balki M.K., Sayin C., 2014, The effect of compression ratio on the performance, emissions and combustion of an SI (spark ignition) engine fueled with pure ethanol, methanol and unleaded gasoline, Energy, 71, pp. 194-201.

[22] Ghazikhani M., Hatami M., Safari B., Ganji D.D., 2013, Experimental investigation of performance improving and emissions reducing in a two stroke SI engine by using ethanol additives, Propuls Power Res, 2, pp. 276-83.

[23] Chen R.H., Chiang L.B., Chen C.N., Lin T.H., 2011, Cold-start emissions of an SI engine using ethanol gasoline blended fuel, Appl Therm Eng, 31, pp. 1463-7.

[24] He B.Q., Wang J.X., Hao J.M., Yan X.G., Xiao J.H., 2003, A study on emission characteristics of an EFI engine with ethanol blended gasoline fuels, Atmos Environ, 37, pp. 949-57. 